\title{
Traditional Factors and Modernization of Village Layout and House Style in Fiji
}

\author{
Mitsuko Sakagami*, Noriko Ando* and Masamitsu OGIHARA*
}

\section{Introduction}

The focus of this paper is cultural architecture and rural life in modern Fiji and its associated problems. Pacific island nations have developed building and architectural styles under the reciprocal influence for hundreds of years. The economies of modern day Pacific island nations depend on tourism, ${ }^{233)}$ and while many tourist come for the palm trees and beaches, many also wish to experience the culture of each country in a traditional setting. For this reason, maintaining of traditional village layouts, architectural styles and building materials is essential. However, over the past decades the building of houses in rural Fijian villages has progressed in a haphazard and ad hoc manner. The aim of this paper is to record and analyze the present condition of building culture in Viti Levu, the main island of Fiji as well as to examine;

(1) How the traditional hierarchical system, chiefdom, impacts on the modern village and,

(2) How European culture, and particularly Christianity, has impacted on the traditional culture.

We visited ten Fijian villages and surveyed three of them on the living environment and the houses. We plotted the layouts of these villages and plans of some houses in the villages and interviewed the people about the village life and the history.

The challenge for these countries is to integrate the traditional and the modern ${ }^{11}$. Japan has experience in this sphere. The conclusion contains recommendations for future rural development in Fiji.

\section{General Information \\ 1 Geography}

The Pacific islands are spread over an area of $1,400,000,000 \mathrm{~km}^{2}$ and are classified into the following groupings: Micronesia, Melanesia and Polynesia, as indicated in Figure 1. Although, Fiji is geographically classified in the Melanesian grouping, it is more ethnically and culturally associated with Polynesia.

The Fiji archipelago is located between the longitude $176^{\circ} 53^{\prime}$ east and $178^{\circ} 12^{\prime}$ west. With the exception of Rotuma, the main islands lie between the latitude $15^{\circ} 42^{\prime}$ and $20^{\circ} 02^{\prime}$ south. The area is approximately $194,000 \mathrm{~km}^{2}$, less than $10 \%$ of which is land. There is a total of about 320 islands, 100 of which are inhabited.

The archipelago forms the eastern outpost of the chain of the high volcanic islands of the continental origin. The large islands of Fiji, Viti Levu and some others, are considered continental islands, rich in mineral resources, so are Papua New Guinea, the Solomon Islands and Vanuatu. Viti Levu is the largest island of Fiji with an area of $10,389 \mathrm{~km}^{2}$, and is the second largest island in the Pacific after Hawaii.

\section{History}

Archeologically speaking, it was described that the Lapita people, who made Lapita pottery, settled in Fiji from Vanuatu (formerly known as the New Hebrides) about 1300 BC and launched into western Polynesia, Tonga and Samoa. Thus, the people of Fiji, Tonga and Samoa were of a single culture and spoke the same language ${ }^{4) 5}$. In 1643, A. J. Tasman discovered the Fiji islands. About the year 1800, traders began to visit for the purpose of procuring sandal-wood or "beche-demer'.

\footnotetext{
*工学院大学建築学科 Department of Architecture, Kogakuin University 1-24-2, Nishi-shinjyuku, Shinjyuku-ku, Tokyo 163-91

Key words : 1)face to face linear form of village layout, 2) centered form of village layout,
}

3) hereditary house foundation, 4)Fijian style house, 5) single room house 


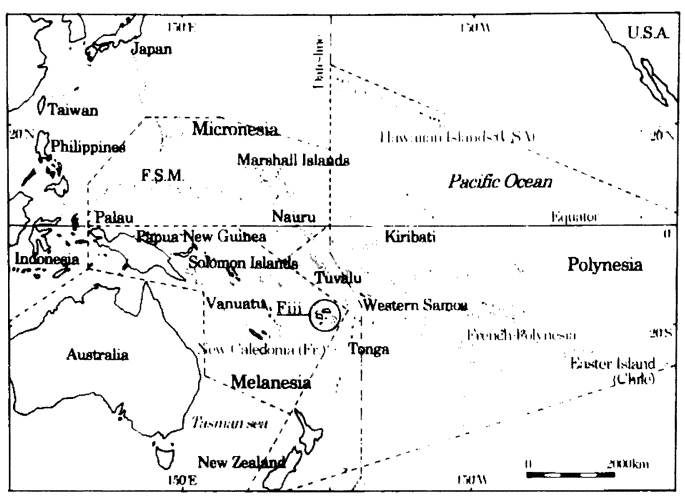

Figure 1. South Pacific Islands

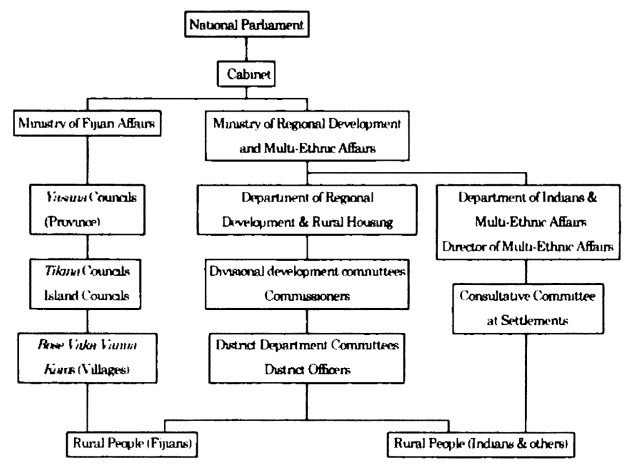

Figure 2. Administrative Structure

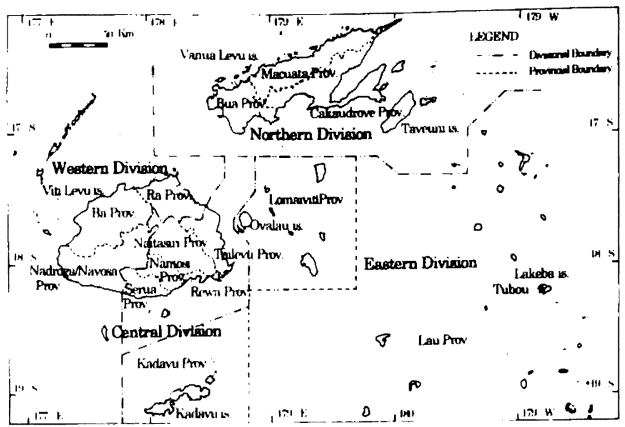

Figure 3. Fiji Islands (except Rotuma is.)

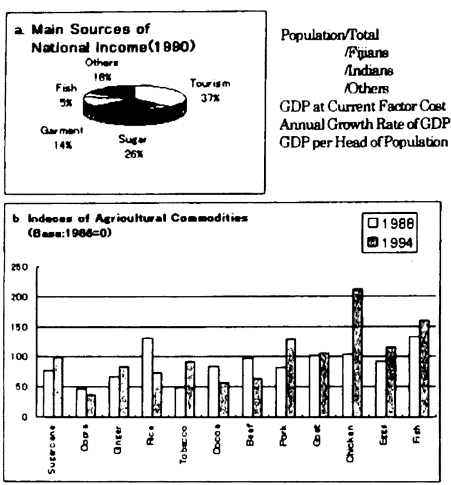

Figure 4. Economical Indices

In those days, some Pacific island nations practiced the custom of human sacrifice and cannibalism. The tribes often fought each other possibly to get more land for their increasing population. The fire arms which the Europeans introduced made the wars violent and ultimately determined the final winner in each island. In Fiji, the conqueror was Ratu Seru Cakobau, the Great Chief of Bau, who resided on the south-east part of Viti Levu. Unfortunately, he was still afraid of Tongan power and decided to make an offer of cession to Britain. Britain accepted his offer in 1874.

After a hundred years as a British colony, Fiji gained its independence from the British commonwealth in 1970. At that time, the Indian population, who settled in Fiji under the colonial policy, out-numbered the Fijian population. In 1987, the Coalition of the National Federation Party and Labour Party, which the Indians supported, won the election. The dissatisfied Fijians retaliated, resulting in a coup d'etat. Fiji was declared a republic and was removed from the British Commonwealth. ${ }^{\text {) }}$ 3 Society

Although the Rural Development Authority has often changed, the administrative sections for Fijians are clearly separated from the other cultures (mainly Indian) by the Native Affairs Ordinance. The administrative structure is shown in Figure 2. There are 4 divisions and 15 provinces (yasana) as shown in Figure 3. Rotuma is. is one province of Eastern Division, however it is located at the northwest end of Fiji islands. Yasanas are divided into tikinas which consisted of villages (koro). There are some cultural differences in each division, including unique dialects in some yasana. We feel that this administrative division relates to the traditional tribes (vanua).

One or several kinships (yavusa) formed one koro. The concept of the yasana and tikina was introduced by the Cakobau's government a short before the colonial rule. Tikinas sometimes shared the same name and area of the yavusa. One yavusa was broken down into some mataqalis (extended family unit). Each mataqali has distinct functions, the turaga (chief), sauturaga (supporter of chief- 
ly authority), matanivanua (official heralds), bete (priest), bati (warrior), mataisau(carpenter) and gonedau (fisherman). We, as well as R. R. Nayacakalou ${ }^{6)}$ in his 1954 research of 3 villages in Viti Levu, verified that the number of mataqalis in one yavusa was not constant. A sub-lineage of a mataqali is called $i$ tokatoka.

\section{Economy}

When Cakobau and the other chiefs offered the government of Fiji to the Queen of England, they did not want to include their soil. So the new government enforced the law on Fijian land. As a result, $83 \%$ of the land still belongs to the natives. This interesting fact, in particular, can be compared to Hawaii and New Zealand where the natives of these countries ended up losing their own land.

The land that belongs to the mataqalis is known as 'Native Land' and is registered and managed by the Native Land Committee. The government-owned land is called 'State Land' and the land which was sold to the Europeans before the law was enforced is called 'Freehold'. Only 'Freehold' land is allowed to be traded.

Today in Fiji, the tourism industry is the largest source of foreign exchange followed by sugar exportation. Figure 4 shows domestic exports and main agricultural products ${ }^{8}$. The village economy itself is based on subsistence farming in the traditional manner ${ }^{9)}$. Besides some mataqalis rent their land to Indian farmers, only a few mataqalis have sought to make better use of their land in efforts like, forestry, cash crops, livestock, etc. .

\section{Village layout}

\section{Outline}

In order to record and analyze the present condition of the building culture in Viti Levu, we must understand the hierarchical system of the traditional society and observe the village layout.

When the west found Oceania, in the early times of the $17^{\text {th }}$ century, it was a turbulent era. Old documents ${ }^{410)}$ and archeological reports ${ }^{11)}$ show some villages with a ring-ditch and a log stockade. But now, it is hard to identify any pattern of the village layout from ordinary view. Fortunately, we used a set of aerial photographs which were taken for the agricultural census in 1990 and used for the statistical research on the nutritional status by the National Food and Nutrition Committee in 1991. This census covered the entire Viti Levu island. We found a linear pattern as a result.

As the object of our research, we selected 7 villages to demonstrate the linear pattern (Naqarawai, Vitogo, Moala, Nawaka, Dratabu, Nasama and Vunavutu) : two villages from their historical background (Tubou and Viseisei) and one is a special village which received the Tourist Award in 1992 because only traditional style houses existed in the village (Navala). Figure 5 shows the locations of the villages, except Tubou (see Figure 3).

We found that the linear form is actually two lines of houses which face each other on opposite sides of a ceremonial open space (rara). It seems to be related with the natural features, however, we did not find any law on it yet. Asesela Ravuvu ${ }^{13)}$, who is a famous Fijian anthropologist, mentioned that physical height is equated with social height. For instance, the person who has higher position can has higher house platform (see Section $\mathrm{N}-1$ ). In addition, Anare L. Gukilau ${ }^{14}$ ) described if the houses face rara formed a double line, people shift the house on the second line not

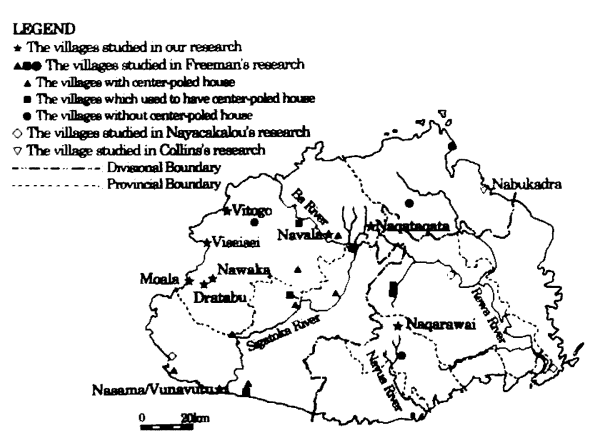

Figure 5. Viti Levu Island to be isolated. We also found a different type of village layout for coastal villages. The houses of the same matagali made a group and the house groups surrounded the rara. We called this type of layout as the centered form. Figure 6 shows the layout patterns of the villages we researched, with an example from the document ${ }^{12}$. We researched in detail on the following three villages: Navala, Naqarawai and Tubou. Table 1 shows the business type by each tikina of the three villages. Navala is included in the Qaliyalatina tikina. The retail usually consists of one or a few small store in a village and the service usually consists of a truck service. 


\section{Navala Village}

Navala is located in the highlands about $20 \mathrm{~km}$ south of $\mathrm{Ba}$, which is the biggest town in the northern area of Viti Levu. There were originally three villages in this area. Navala, consisting of one yavusa which was composed of six matagalis, is a planed village in which two villages were merged about 80 years ago. People planed to build one primary school for the three villages. The highest chief offered the land for both the school and new village and proposed to live together with the other chiefs.

The pattern of the village layout is a T-shaped form (see Figure 7-a.c). One carpenter, who

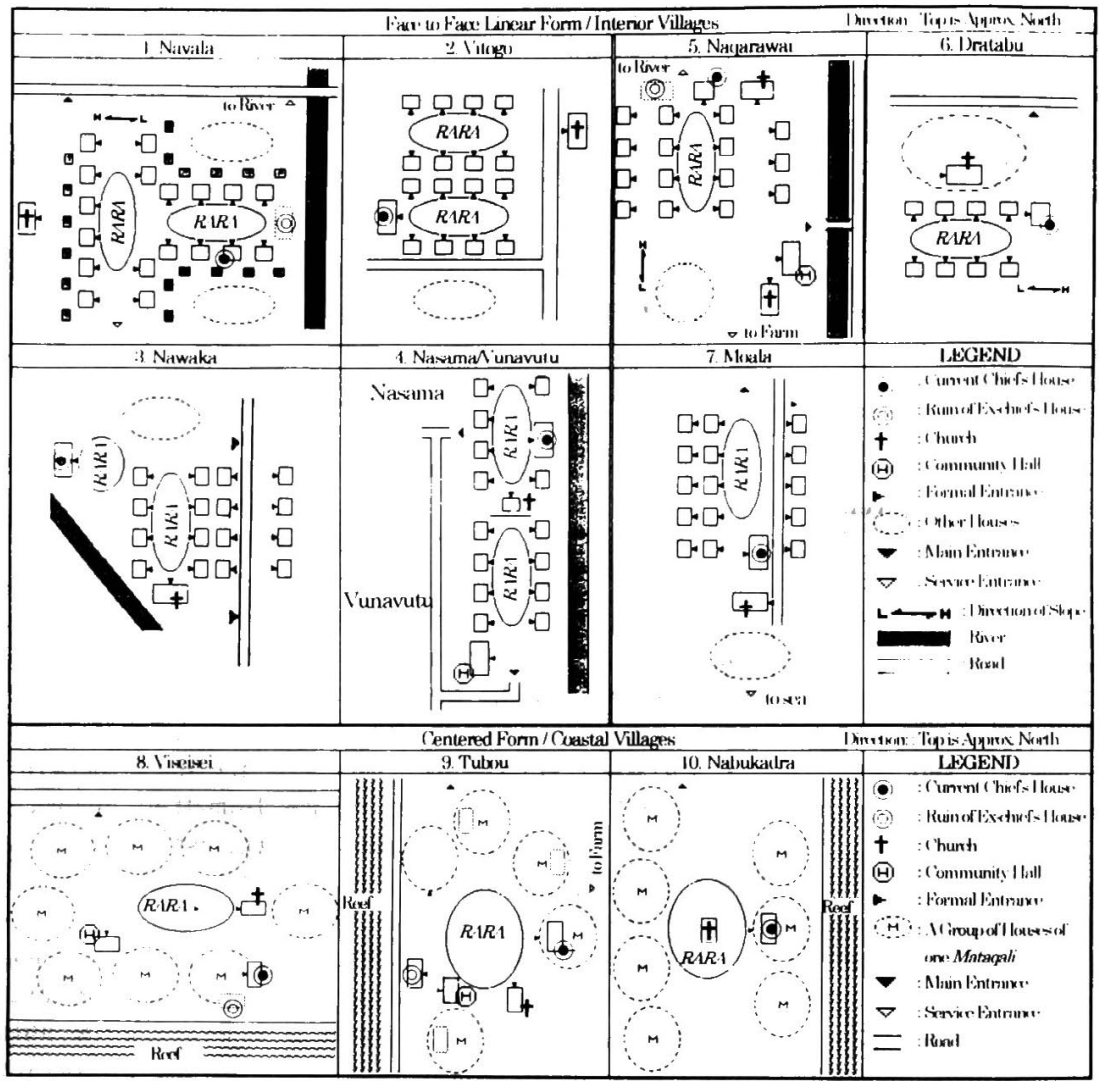

Figure 6. Comparison of Village Layout Patterns

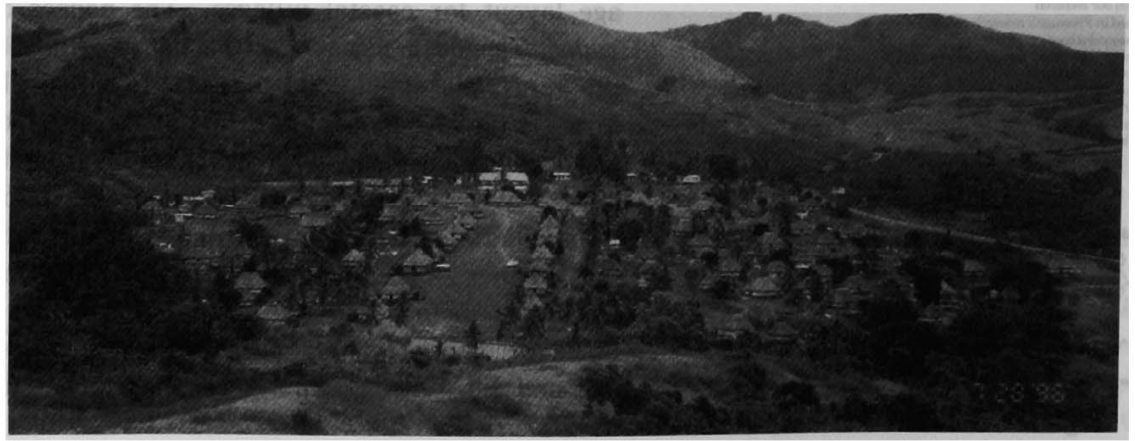


was invited to build the new village, created the image of a cross with the catholic Church at the top of the " $T$ ". Each line of the "T" is the usual face to face linear form.

There are only a small percentage of traditional style houses left in Fiji. However, in Navala, all the houses in the "house area" are constructed of the traditional style. Outside the "house area", we found that a church, the primary school and teacher's quarters were built of concrete blocks. The layout of the houses which are not part of the $T$ shape is random. This suggests that the village is overcrowded. As for the economic situation in Navala, we found that there is feasibility of higher employment and educational standards compared to other highland villages, because of the close proximity of towns such as $\mathrm{Ba}$. There is bus service between Navala and $\mathrm{Ba}$ which runs twice a day, except on Sundays, and takes about two hours. We also found that their standard of living is not much higher than the other highland villages. They have no electricity or flush toilets ; water is piped from a mountain to the water places in the village and some families have a stool for their toilet while other families do not own a toilet. Several families use one water place. In actuality,

Table 1. Business Type by Tikina

\begin{tabular}{|c|c|c|c|c|c|c|c|c|c|c|c|}
\hline TIKINA & 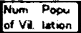 & Reras M & Mence & $\begin{array}{l}\text { Cosh } \\
\text { Cropo }\end{array}$ & $\begin{array}{l}\text { Live Fi } \\
\text { Hoch in }\end{array}$ & & Fores $\mathrm{S}$ & $\begin{array}{l}\text { Sor } \\
\text { vice }\end{array}$ & $\begin{array}{l}\text { Poid s } \\
\text { Emp : }\end{array}$ & $\begin{array}{l}\text { Such } \\
\text { sat }\end{array}$ & \begin{tabular}{|l|}
$\begin{array}{l}\text { Total } \\
\text { (s) }\end{array}$ \\
(fss)
\end{tabular} \\
\hline INA & 21320 & 0.5 & 0 & 37 & 07 & $\overline{0}$ & 0 & 0 & 0 & 941 & 100404 \\
\hline NAQARAV & $\begin{array}{l}3 \quad 719 \\
\end{array}$ & 3.6 & 0 & 21 & 86 & 0 & 0 & 3.6 & 0 & 82.1 & $100 \quad 140$ \\
\hline LAKEBA & $22 \quad 2371$ & 2.7 & 01 & 32.6 & 03 & 43 & 0 & 1.2 & 17.2 & 417 & 1001042 \\
\hline
\end{tabular}
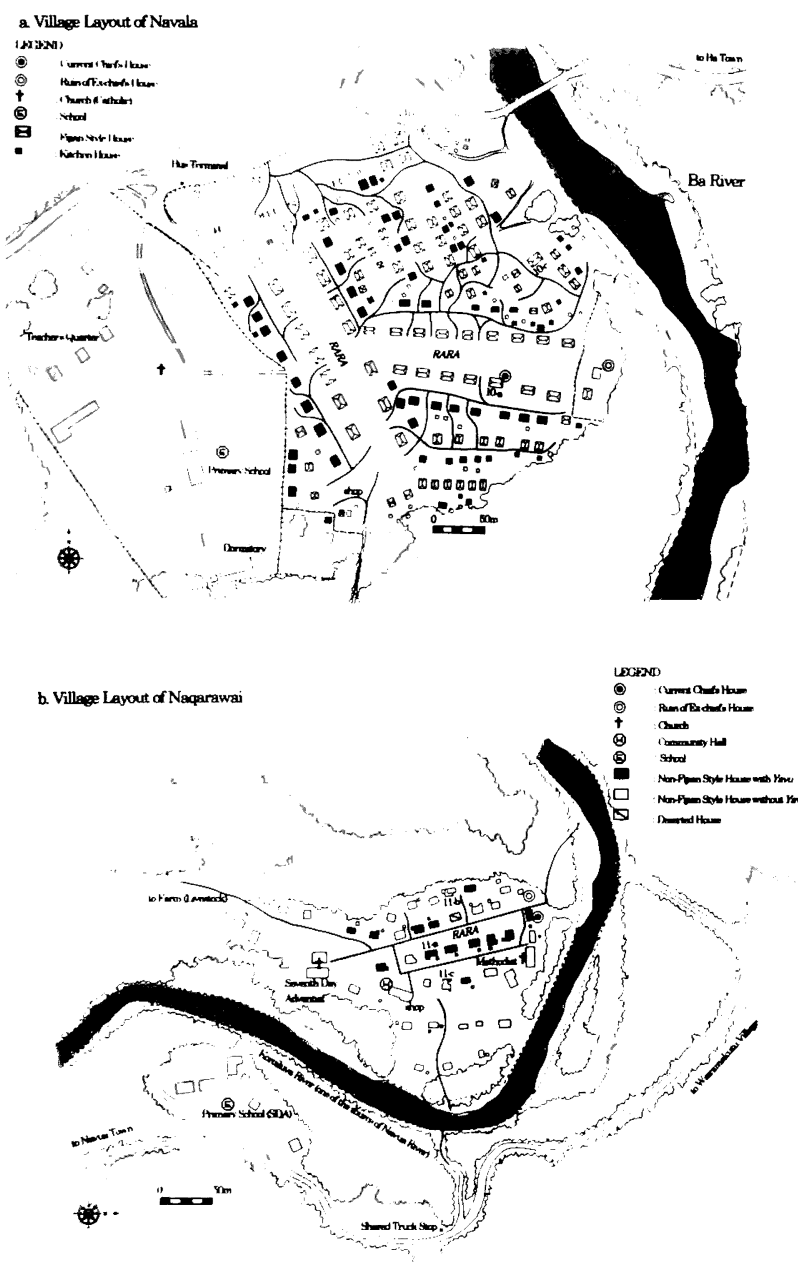

Figure 7. Navala Village and Naqarawai Village people grow yaqona i) as cash crop and keep goats ${ }^{\text {ii) }}$ for selling, but there is no paid employment in Navala (see Table 1).

\section{Naqarawai Village}

Naqarawai is located in the highlands about $40 \mathrm{~km}$ west-northwest of Suva, the capital of Fiji and about $20 \mathrm{~km}$ north of Navua, the central town of the district. It consists of one yavusa which was composed of two mataqalis.

The pattern of the village layout looks like a double face to face linear form as seen in an aerial photograph. But considering the front of each house, it is clear that the layout is a basic face to face linear form with both sides constituting of a second line of houses (see Figure $7-b)$. The valley side has more space so the houses have enough utility space, just like the rara. But the positions of the families are lower than the families on the hill side.

Although Naqarawai is located near the capital, there is only truck service once a day, except on Sundays for both the people and items. The service between Wainimakutu, which is $1 \mathrm{~km}$ from Naqarawai and Suva via Navua, takes more than three hours. Transportation is one of the more serious problems for the village. However, unlike Navala, their standard of living is much more modernized. Every house has its own flush toilet and water supply which is piped from a mountain while the main foot paths in the village are paved with concrete slabs. Although they have no electricity for their houses, some electric lights with solar battery systems are used in the community hall. Main products of the village are dalo ${ }^{\mathrm{ii})}$, yaqona and bananas. In addition, 
one family keep daily farm (see Table 1).

The concrete path spoiled the ceremonial character of the rara. However, people still keep it very neat (see Figure 7-d). Currently, most of the ceremonial things are done in the community hall. We found that some families have another house near town. We also noticed that there were some vacant houses on the front line.

\section{Tubou Village}

Tubou is the capital village of Lakeba island, which is a raised limestone island located about $300 \mathrm{~km}$ east of Suva. It is one of the most important historic villages and home of Ratu Mara, the current President and former Prime Minister and the head of the Great Council of Chief. It consists of one yavusa which was composed of five mataqalis. Ratu Mara's copra plantation is a main industry, followed by fishery (see Table 1).

The standard of living is absolutely above average and not comparable with other villages. The culture of the Lau province is very different from the other parts of Fiji. They were influenced by Tonga in many ways. Lau had a good source of timber to make big canoes unlike Tonga and Samoa. Some carpenters came from Tonga and Samoa to built canoes and taught the islanders how to build a Tongan style house ${ }^{15)}$. So we think it is important to consider the history and the regional differences of architectural culture of Tubou.

Several archeological studies describe ${ }^{15)}$ how a village is often moved to another location based on circumstances beyond its control. We found that Tubou was moved from about $1 \mathrm{~km}$ inside of the current location soon after a particular Methodist pastor arrived on Lakeba in 1835.

The remains of the old village site has already been covered by the rain forest. We could only see that the yavu (house platform) of the bete's house was still the highest place in the area. We could also recognize the border of the village and the yavu of the gatekeeper's house outside the border. Simon Best ${ }^{15)}$ completely researched this area in between late 1975 and 1978 . So, we hope that this area will be restored and utilized as a cultural resource in the future.

The center of the village is a large rara which faces the sea and is surrounded by a church, the formar chief's house, the current chief's house, a residential area for church functions and the ruins of the bete's house. We refer to this layout type as a centered form (see Figure 8). The village is separated into many small areas which are each mataqali's place and each area has its own name. Outside the center, there is the ruins of the Tongan chief's house who had threatened Cakobau and convinced him to offer Queen Victoria his government. Additionally, there are the settler's place (Levuka village) and the public facilities. We found that a descendant of the gatekeeper is living directly in front of the gate to Ratu Mara's house. He informed us that his ancestor was the first person who accepted Christianity and decided to develop the current site of the village, a place more

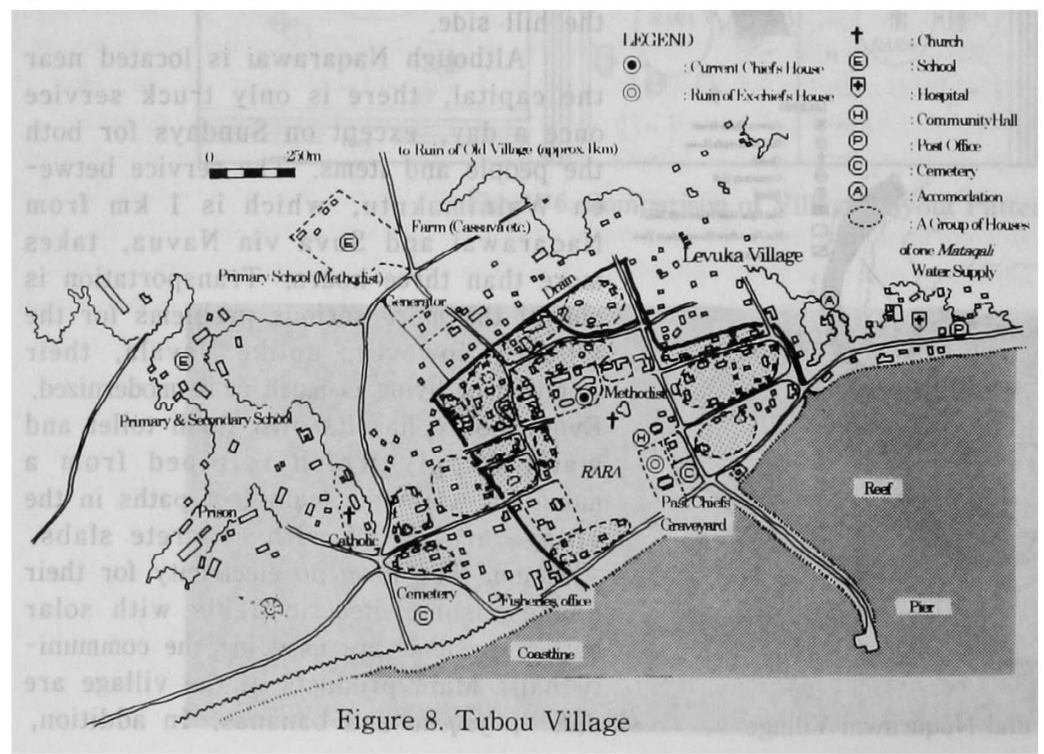
open and close to the sea. After the development, he asked the chief to move.

In addition to this story, the layout of the ruins of Tongan chief, the bete and the gatekeeper's house suggests a relationship between their power. The former chief's house was once used as a community hall. However, a new hall was built next to the church last year. Thus, the house was closed and reserved as a private house of the current chief. 


\section{House Style \\ 1 Outline}

There are not so many studies that have been conducted on the architecture in the South Pacific

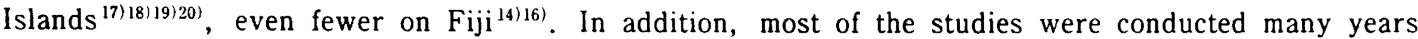
ago. This makes it very difficult ${ }^{21)}$ to verify the facts which were described in such studies. We did find one resent study performed in 1986 by Susan Freeman ${ }^{21)}$.

Freeman paid particular attention to the center-pole house which is one of the building styles she picked up from past documents and researched it throughout 17 villages in Viti Levu (see Figure 5). We verified the facts in her study. In addition, we explored the traditional style house as a matter of modern living. Below is our discussion of the different architectural building styles comparing the following three villages; Navala, Nagatagata and Naqarawai.

Navala was classified as a village of the center-pole house by Freeman which we also verified. Nagatagata is located in an area where houses used to have a center-pole but we could not verify this partly due to the fact that we did not have adequate time to check out all the houses. Naqarawai is located in an area without the center-pole construction.

Several old documents ${ }^{10)}$ show different types of houses, like the men's house (bure), the guest house (icili), the sleeping house (vale ni moce) and the temple (bure kalou). Unfortunately, we could only recognize the ordinary style house and the utility house during our research. Thus, we will focus on the ordinary and utility houses.

Ravuvu ${ }^{13)}$ mentioned the hereditary house platform (yavu) and the concepts on space and openings of the Fijian house. He also mentioned that physical height is equated with social height as we stated above. The platform is raised earth and sometimes has a stone wall. The traditional Fijian house is generally a large, high gabled ${ }^{i v)}$, rectangular structure without internal partitions (Ravuvu). Figure 9 captures a social structure of the immense space and a building structure.

\section{Navala Village}

The house style is just like what Ravuvu mentioned. It is a rectangular shape which is about $10 \mathrm{~m}$ by $6 \mathrm{~m}$, on average and has a thatched high-raised hip roof. The village site is sloped and the vertical line of " $\mathrm{T}$ " is on a parallel with the slope. Most of the houses have a platform but there are also some houses built directly on the ground. All poles are deeply built into the earth.

Only houses located on the " $T$ " have a center-pole. Freeman concluded the purpose of a center-pole denotes a spiritual connotation. In the Japanese tradition, a center-pole which decorated with pictures and flowers, reflects "daikoku-bashira" (a center-pole in the Japanese house), but we did not verify the real function of a center-pole by ourselves yet.

The floor is covered with some leafy mats which are woven with Pandanus leaves, known as Fijian mats (ibe). Under the mats, there is a thick dry grass layer on the earth. In some houses, a $\log$ is laid under the mats to serve as a long pillow.

The walls are generally made of woven bamboo shreds, but there were three houses which had thatched walls. These are the houses of three chiefs and have individual designs. In modern times, these designs are created from reeds woven with vines while in the past, these designs were made from the string of coconut husk fibers (magimagi). One house had a beautiful display of patterns on the inside wall. This house also had a specific outside form similar to a beehive, no interruption from the peak of the roof to the ground (see Figure 10-c).

There are typically two or three doors on the houses with no windows (see Figure 9-a). There is a formal entrance which is used for the chiefs and guests who are welcomed by the chief, which usually faces to the rara. There is also another side door which is used more like a window. There are no steps, only railings on most of the houses. Old persons usually watch outside from these openings. People usually use an end door and the kitchen house is located close by the door. The kitchen houses which have no yavu also have no formal entrance.

Behind the main house, there is a kitchen house (vale ni kuro) and a few houses which are owned by members of the same $i$ tokatoka. The $i$ tokatoka usually shares a kitchen house and a toilet (vale lailai). The shape of the kitchen house is similar to the main house but much smaller. The remarkable difference between the ordinary house and the kitchen house is the ridge decoration (balabala, see figure 9-b). A burned coconut $\log$ is used for the ordinary house while a bamboo log 


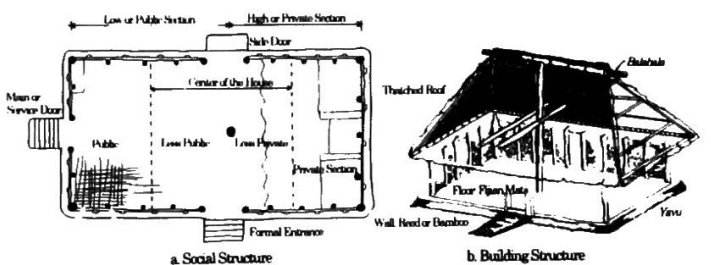

Figure 9. The Structure of Traditional Fijian House (eg Navala's chiefs house)

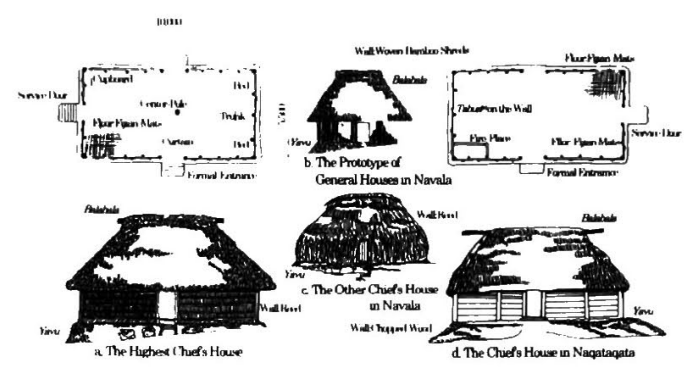

Figure 10. Houses in Navala and Nagatagata

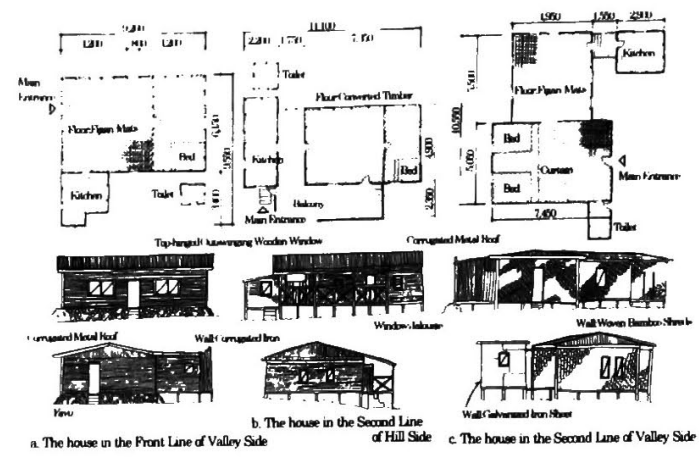

Figure 11. Houses in Naqarawai

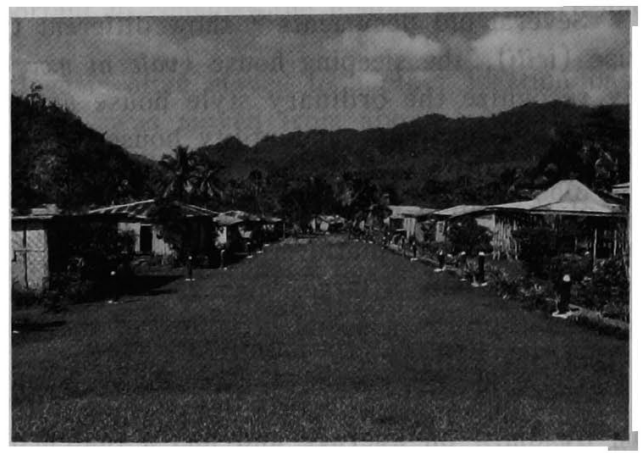

is used for the kitchen house.

\section{Nagatagata Village}

Nagatagata is located in the center of Viti Levu. People from many villages in this area must walk through the bush to get to the road, more than $1 \mathrm{~km}$. We visited Nagatagata accidentally. Although we did not have enough time to conduct adequate research, we did find several remarkable characteristics. First, the material on the walls is converted timber. The reason why people in this area use timber rather than bamboo or reed is that there is a sawmill near the village and timber is the easiest material for them to get. Second, many houses have a square shape.

The chief's house is a rectangular shape and almost same size as the one in Navala. There are three doors but no window as in Navala. However, unlike Navala, the center-pole form is not used. There is a fireplace at the private side of the formal entrance. The fireplace is made directly on the earth floor where the mat was removed and divided from the ordinary floor by some logs. People in Navala also described that they sometimes build a fireplace in a house where the weather gets very cold, however we did not see it.

\section{Naqarawai Village}

In spite of the bad condition of the transportation to the village, the houses are built from mostly industrial products. We could not determine if the reason for the higher standard of living is the result of the Chiefly mataqali's power, the Church's power (Seven Days Adventist), etc... The school and the flush toilets were supported by SDA and the community hall and the solar battery systems by the government. The walls are converted timber, corrugated metal or woven bamboo shreds and every roof is corrugated metal. So, the rise is generally very low and some houses have shed roofs. The house plans also become more complicated. Some houses still have the original simple plan while other houses clearly have some European plans. The European plans differ in that they have some internal walls. One house also had a balcony and another had a gambrel roof. We found that we could see several houses that combined the house and utilities together as seen in Figure 11. 
Every house had a few windows. They had top-hinged outswinging wooden windows or "jalousie" windows.

We recognized remains of the yavu of some houses which are on the first line beside the rara. Most the house had an elevated wooden floor. The old yavus were washed away by floods for a long time and new yave is not important for them ${ }^{13)}$. A few houses were built directly on the ground.

There was a community hall, a rectangular room about $18 \mathrm{~m}$ by $6 \mathrm{~m}$ in size, which also combined a kitchen and a small store. The same materials used for the houses were used for the hall. The proportion of the hall is very similar to several sketches of the guest house (icili).

\section{$\mathrm{V}$ Conclusion}

If you stand on top of the hill, you could see a beautiful view of the valley which was dotted with thatched houses in a forest (see Figure 7-e). Such an exotic view has a great appeal to tourists. We think it is a miracle that this view still exists under the powerful influence of modernization. A bure kalou, which has a particularly high-raised roof, was reconstructed in the culture center of a resort hotel. Such a structure is already far from the people's life. Hashimoto ${ }^{7 /}$ analyzed the Christianity in Fiji on the relationship with the native religion and described the peculiarity of it. We also found that some villages, especially the chiefly villages coordinate the tradition and the modernization very well. They keep the traditional order, such as the village layout, with a church at the top of it. Hashimoto explained the coordination system itself is their own culture. But the increasing population rate of Indians once made the Fijian afraid.

The Fijian people are seeking their own identity in a combined unit of their tradition and Christianity ${ }^{7}$. It will easily lead to racism (see Section II-2). We think the people should seek their own identity into the traditional skills.

A regular layout pattern was spoiled in some villages because of the overpopulation. At the same time, the drain of young people from villages become noticeable in the highlands. The depopulation is not too serious yet but most have an influence to keep traditional houses by the village community. The case that some rich families in a village have other houses outside the village as like in Naqarawai is increasing. In this case, the family still can keep up the base of their life in a village with special land ownership system.

Generally, People are not inconvenienced enough to change their life style. In addition, due to the lack of money, they seem content with the quality of their houses. The most significant thing for them are the duties of a member of their own mataqali. For instance, they are the duties bound to attend and present proper gifts at some ceremonial occasions. We think the duties almost coincide with the Japanese "giri" in the villages.

In conclusion, it is necessary to improve living conditions in most of the highland villages, while at the same time maintaining architectural integrity. Policy guidelines should be devised so that further development and modernization in Fijian villages takes into account traditional cultural architecture.

Traditional Japanese culture has much in common with Pacific Island cultures. For this reason our experience in moving from the traditional to the modern, while maintaining architectural integrity may be a useful blueprint for these countries. We know there should be some policy guidelines which do not force the people to stay in a primitive life style but rather balance modernization with tradition.

\section{Notes}

i ) yaqona: Piper methysticum-a plant the roots of which are prepared and used as a social and ceremonial drink (also called as yaqona) popular in Fiji and other Pacific islands.

ii) Goat: Hindus are forbade to eat beef because cattle are God for them and Muslims are forbade to eat pork because it is unhealthy meat. In Fiji, Hindus and Muslims have a close relationship and they cook goat or chicken for a ceremony as like a wedding. So anyone can join the ceremony. There are large population of Indians around $\mathrm{Ba}$. Thus, goat as livestock are popular in this area.

iii) dalo: colocasia esculenta-a staple starchy root crop of the Fijians. There are many different types of dalo. Yam is also Fijian's favorite food and more seasonal crop. People used to have 
to present the first yam in a year to their chief. Cassava is a popular root crop and very easy to grow, but less nutritive value.

iv) gabled: We did not find any traditional Fijian house with a gabled roof even in old documents. There are some with a hipped roof which end eave has a slope of almost right angle. We guess Ravuvu misunderstood the word.

v) In 1997, The Constitution Amendment Bill passed through the Parliament. Fiji joined the British Commonwealth of Nations again.

\section{References}

1 ) Schneider, Bertrand (1996) : Kokusai Enjyo no Genkai, Asahi Shinbunnsha, pp. 53-74

2 ) Hori, Takeaki (1997) : Minami-Taiheiyou no Hibi, Nippon Housou Kyoukai Shuppansha, pp. 193202

3 ) Pacific Economic Cooperation Council (1995): Pacific Eco-Tourism and Investment Prospects Project (Phase 2), Case Study : Fiji, the Japan National Committee for Pacific Economic Cooperation, pp. 1-53

4) Ishikawa, Eikiti (1992) : Oceania, Tiiki kara no Sekaisi, vol.17, Asahi Shinbumsha, pp. 49-54

5 ) Gravelle, Kim (1979) : A History of Fiji, The Fiji Times and Herald Ltd., pp. 5-246

6 ) Nayacakalou, R. R. (1978) : Tradition and Change in the Fijian Village, Institute of Pacific Studies of the University of the South Pacific, pp. 1-139

7 ) Hashimoto, Kazuya (1996) : Kirisuto-kyou to Shokuminti Keiken, Jinbun Shoin, pp. 9-268

8 ) Bureau of Statistics (1995): Current Economic Statistics, Bureau of Statistics, Fiji Government, pp. 1-120

9) Ministry of Fijian Affairs (1995): Provincial Profile Report, Fiji Government, pp. 10-78

10) Roth, Jane, and Steven Hooper, ed. (1990): The Fiji Journals of Baron Anatole Von Hugel, Fiji Museum, pp. 3-452

11) Parry, John T. (1987): The Sigatoka Valley Pathway into Prehistory, Bulletin of the Fiji Museum, no. 9, Fiji Museum, pp. 1-134

12) Collins, Graham (1977) : Maraia Lives in a Fijian Village, Longman Paul Ltd., pp. 1-24

13) Ravuvu, Asesela (1983) : The Fijian Way of Life, Institute of Pacific Studies of the University of the South Pacific, pp.1-116

14) Gukilau, Anare L. (1978) : Issues in Fiji with Architectural Implications, University of Auckland, pp. 3-36

15) Best, Simon (1983): At the Halls of the Mountain Kings. Fijian and Samoan Fortifications: Comparison and Analysis, Journal of the Polynesian Society, pp. 385-441

16) Williams, Thomas (1858) : Fiji and Fijians vol.1, The Islands and Their Inhabitants, Fiji Museum, pp. 78-85

17) Ishige, Naomiti (1971) : Jyuukyo-Kuukan no Jinruigaku, Kajima shuppankai, pp. 175-226

18) Ishikawa, Eikiti (1971): Sumai no Genkei I, Kajima shuppankai, pp. 12-21

19) Aoyagi, Matiko (1971) : Sumai no Genkei I, Kajima shuppankai, pp. 94-105

20) Itou, Seiji (1973) : Sumai no Genkei II, Kajima shuppankai, pp. 193-203

21) Freeman, Susan (1986): The Center-poled Houses of Western Vitilevu, DOMODOMO, Fiji Museum Quarterly, IV-1, pp. 2-19

\section{フィジーの集落形態と住居における伝統とその近代化}

\section{坂上みつ子・安藤 典子・荻原 正三}

\section{I 研究の目的}

一口に途上国と言っても，それぞれの国が抱え る問題は微妙に違う。南太平洋島嶼国の場合それ
は，それぞれの国の小ささであり，また，先進国 からの距離の遠さが際立っている事である。一方 我が国の過疎問題と共通の要因が見られはしない

Key Words：1)対面線形型集落配置，2)求心型集落配置，3）世襲制住居基壇，4)フィジー式住居，5)一室住居 
だろうか。これらの国々は環太平洋文化圈に位置 し，我が国の文化との関わりも少なくない。

以上の観点から，これら島嶼国のリーダー的存 在であるフィジ一共和国を調査対象として, 首長 制社会が西欧文化（特にキリスト教）の影響によ り変容していった結果, 集落や住居にどのような 変化が起こったのか，また，それらの現状から読 み取れるものは何かを探る事によって，これら島 䰸国における地域環境と居住地計画へのアプロー チが可能になるであろう。

また，これら島嬹国では観光産業への依存の度 合いを強める傾向にあり，そのサステナビリティー の為にも，それぞれの民族のアイデンティティー の確立が重要であるが, 彼ら自身の文化を捉え直 し，後世に伝えていくという事に対して，集落や 住居の記録分析が少なからず役立つであろう。

\section{II フィジーの概要と特徵}

オセアニア地域はミクロネシア，メラネシア， ポリネシアに大別される。フィジーは地理的には メラネシアに含まれるが，人種的，文化的にはポ リネシアとの関係が強い。

1874年英国の植民地となる。1970年に独立国と なった後も英連邦の一員であったが，1987年にフィ ジー人系軍人のクーデターにより共和国となり，

英連邦から分離した。植民地時代に入植したイン ド人の人口が全人口の約半数を占めており，この 事が文化的にも社会的にも，他の南太平洋島嶼国 とは異なった特徽となっている。

フィジー人とその他の人種（主としてインド人） に対する行政組織は明確に分かれている。図 3 の 様にフィジー全体は四つの“division”に分けら れ，その下に15の“yasana (province)”がある。

“division”毎に文化的な相違が見られ，“yasana” 毎にも方言を持つ等, 統一前の部族集団との関係 が深いと考えられる。

血族集団である“yavusa”が単一，または幾つ か集まって“koro（village）”を構成している。

“yasana”とその下の行政組織である, “tikina” は植民地時代以降のものだが，ナバラ村の様に “tikina”と“yavusa”が同じ名前で, 同じ範囲 の集団を指す事がある。“yavusa”は幾つかの “mataqali”（マタンガリ／親族集団）に分かれ る。“mataqali”の下の集団は複合家族集団とみ なす事が出来, “i tokatoka”と呼ばれている。

“i tokatoka”は殆どは数家族で構成されている が，1家族の場合もある。

英国植民地となるにあたって，当時の王と首長 達は政権は委譲したが土地の所有権は手放さなかっ たので，83\%の土地が “mataqali”の所有地とし て現在まで受け継がれている。

“mataqali” 所有の土地は “Native Land” と呼 ばれ，国有地は“State Land”，土地所有法が確 立する前に欧米人の所有となってしまった土地は “Free hold”と呼ばれる。“Native Land”は “Native Land Committee”に登録管理されてお り, “Free hold”だけが現在売買の対象となって いる。

村の産業は基本的には原始的な自給自足農業を 中心としており，地域によってはサトウキビやコ プラのプランテーション, 松の植林, 生姜の栽培, 野菜の栽培等が導入されている。しかし村の首長 などの有力者が個人的に行っている場合が多く， 首長制による階層社会が村ぐるみで新しい産業に 取り組む事への障害になっている様に思われる。

\section{III 集落形態}

ヴィチ・レヴ島を中心に10ヶ所の村を調査した。 1990年撮影の航空写真から，一定のパターンを示 す村を調査行程を考慮しつつ 7 ケ村選択し，歴史 的背景を持つッンボウ村, ビセイセイ村と, 伝統 的な住居だけで構成されている唯一の村であるナ バラ村をこれに加えた。

図 6 は、これらの集落構成をパターン化して比 較したものであり, 最後の一つは調査したもので はないが，海岸の集落の例が少なかったので文献 からの例を比較の為に挙げたものである。

“rara”と呼ばれる広場が中心となり，階層社 会を如実に示す配置が共通している。教会が要の 役割を果たしている事も良くうかがえる。航空写 真で顕著だったのは, 対面線形型配置であり, 多 重のものも見られた。海岸の集落では求心型配置 であった。多重配置についてGukilau'4) は, “rara” に面して住戸の配置が 2 列になる場合，疎外感を 防ぐために互い違いに配置すると述べている。

ナバラ村では線形配置がT字型を構成している 
が, 聞き取り調査の結果, これは村の教会がカト リックである事から，集落移転時に教会を頂点と した十字型として計画されたという事が判明した。 ナンガラワイ村では, 航空写真からは 2 列とも見 えた線形配置が, 各列が多重になっている事が, 各戸の正面を考慮する事によって明らかになった。 ッンボウ村では, 旧集落跡の確認と, 求心型配置 における，“mataqali”毎の住居区画の経緯や各 区画の名前を確認する事が出来た。今回は時間の 関係上, 調査対象としなかったが, トンガ式の住 居などトンガの影響について今後の研究課題とし たい。

\section{IV 住居}

Freeman ${ }^{21)}$ は過去の文献から抽出した住居形態 のうち, 中心に心柱を持つ形態と持たない形態に 注目し，1985年にヴィチ・レブ島全域の17の集落 においてその分布状況を調査している(図 5 参照)。

我々はFreemanの調査報告を再確認する事と, さらにそれら伝統的な住居と現在の生活との関わ りに重点をおいて調べるべく，さらには集落形態 の調査との関連で調査地を決定した。Freemanの 調査地でもあるナバラ村は心柱を持つ地域として 明記されており, 我々の調査でも確認する事が出 来た。ナンガタガタ村は心柱をかつて持っていた という地域に位置する。今回の調査では日程の都 合上限られた住戸しか見ていないが，心柱は確認 していない。ナンガラワイ村は心柱を持たない地 域に位置する。

Ravuvu13)は, 各家は“yavu”と呼ばれる基壇 の上に建てられ，その基壇の高さが所有者の階層 の高さを示し, “yavu”が世裝される事により家 柄の象徽になっていると述べているが, ナバラ村 ではこの事も確認する事が出来た。

ナンガタガタ村はナバラ村ほどには組織的に伝 統が維持されている訳ではないが, 地域性と材料, 形態の違いが明らかであった。

ナンガラワイ村は交通が不便な割には工業製品 が入り込んでおり, 平面も伝統的な一室型住居か ら多室型住居への移行をうかがわせるものや, バ ルコニー等を持った，いわゆる西欧型を基盤とし たものと同時に，一部の住居には“yavu”も確認
する事ができた。

\section{$\mathrm{V}$ 結論}

ナバラ村の谷間に草葺き屋根の住居群が広がる 景観は大変美しいが, 西欧文化の影響が大きい今 日では，その存在は奇跡に近いという気がする。 リゾートホテルが経営するカルチャーセンターに は屋根の高い宗教建築も復元されているが, これ らは既に人々の生活文化からはほど遠いものになっ てしまっている。

橋本7)はフィジーにおけるキリスト教と伝統的 な宗教との関わりについて分析しているが, 我々 も幾つかの “koro”，特に階層の上位に位置する “koro”において伝統と近代との見事な融合を目 にする事が出来た。橋本は融合の為の手続きを持 つ事こそが彼らの文化であると述べている。

多くの集落で過密から集落のレイアウトに規則 性が失われ，一方，山間部の集落で特に若年層の 流出が顕著になりつつある。過疎には至っていな いが，共同体による伝統的な住居の維持には大き く関係していると言えるだろう。ナンガラワイ村 の様に富裕層が集落外に家を持つという例も増え てきている。しかしこの場合も, 独特の土地所有 制度により，集落内に生活の基礎は確保されてい る。住環境改善に真剣に取り組むほど不自由はし ていないが, 住居の質の向上を求めるほどの余裕 も無いのが現状である。

結論としては,山間部の集落には住環境改善の 必要性が多分にあり，市街地周辺の集落では修景 の為の何らかの政策が早急に必要だという感想を 持った。そしてその政策は伝統の技術を向上させ， さらに伝統の技術と材料の供給システムを確立す るものが望ましいだろう。その中には, 集落計画, 住居整備についての住民による検討の必要性も含 まれるだろう。

伝統と近代化のバランスを考虑した新しい考え 方を模索するべく，より踏み込んだ研究を今後の 課題と考えている。

(1997年 9 月 2 日 受理) (1998年 3 月 12 日 再受理) 